\title{
Nitrate Nutrition and Temperature Effects on Wheat: Photosynthesis and Photorespiration of Leaves
}

\author{
D. W. LAWLOR ${ }^{1}$, F. A. BOYLE ${ }^{2}, A . T . Y O U N G^{1}, A . J . K E Y S^{2}$ AND \\ A. C. KENDALL2
}

${ }^{1}$ Physiology and Environmental Physics Department, Rothamsted Experimental Station, Harpenden, Herts. AL5 2JQ, U.K.

${ }^{2}$ Biochemistry Department, Rothamsted Experimental Station, Harpenden, Herts. AL5 2JQ, U.K.

Received 24 June 1986

\begin{abstract}
Lawlor, D. W., Boyle, F. A., Young, A. T., Keys, A. J. and Kendall, A. C. 1987. Nitrate nutritıon and temperature effects on wheat: photosynthesis and photorespiration of leaves.-J. exp. Bot. 38 : $393-408$

Photosynthetic and photorespiratory carbon dioxide exchange by the third leaf of spring wheat (Trittcum aestivum cv. Kolibri), was analysed for plants grown at $13 / 10^{\circ} \mathrm{C}$ (day/night temperature) and $23 / 18^{\circ} \mathrm{C}$ with two rates of nitrate fertilization (a basal rate, $-\mathrm{N}$, and a 4 -fold larger rate, $+\mathrm{N}$ ) and, in some experiments, with two photon fluxes. Net photosynthesis was greatest at the time of maximum lamina expansion, and for leaves grown with additional nitrate. Maximum rate of photosynthesis, carboxylation efficiency and photochemical efficiency at maturity were slightly decreased by nitrate deficiency but photosystem activity was similar under all conditions. As leaves aged, photosynthesis and photochemical efficiency decreased; carboxylation efficiency decreased more than photochemical efficiency particularly with basal nitrate. Low oxygen increased the carboxylation and photochemical efficiencies, and increased the maximum rate of assimilation by a constant proportion in all treatments. Photorespiration, measured by $\mathrm{CO}_{2}$ efflux to $\mathrm{CO}_{2}$-free air, by ${ }^{14} \mathrm{CO}_{2}$ uptake, and from compensation concentration, was proportional to assimilation in all treatments. It was greater, and formed a larger proportion of net photosynthesis, when measured in warm than in cold conditions but was independent of growth conditions. Assimilation was related to RuBPc-o activity in the tissue. Relationships between photosynthesis, photorespiration and enzyme complement are discussed.
\end{abstract}

Key words-Wheat, leaves, nitrate nutrition, temperature effect, photosynthesis, photorespiration.

Correspondence to: Physiology and Environmental Physics Department, Rothamsted Experimental Station, Harpenden, Herts. AL5 2JQ, U.K.

\section{INTRODUCTION}

Nitrate fertilization of crops influences many stages in the production of dry matter, e.g. by increasing leaf area and light absorption (Bowes, Ogren, and Hageman, 1972), and by increasing both the rate and the efficiency of photosynthesis (Evans, 1983). The efficiency of carbon dioxide assimilation is determined by the rate of gross photosynthesis and by the rate of $\mathrm{CO}_{2}$ loss in photorespiration, both of which are related to the amount of ribulose bisphosphate carboxylase-oxygenase enzyme (RuBPc-o) and its characteristics, and by dark respiration (Farquhar and von Caemmerer, 1982).

(C) Oxford University Press 1987 
In a preceding paper (Lawlor, Boyle, Kendall, and Keys, 1987a) we showed that activity (per unit leaf area) of some enzymes of the photosynthetic and photorespiratory carbon and nitrogen cycles, changed in proportion to soluble protein content when nitrate supply, temperature and age were varied. A constant ratio of chlorophyll to RuBPc-o was maintained, suggesting close linkage between light harvesting and the processes of carboxylation. The ratio of RuBPc to RuBPo activity, measured under constant conditions, was the same in protein from leaves grown under different nitrogen nutrition and temperature. A constant ratio of photorespiration to photosynthesis at a particular temperature would, therefore, be expected. However, Thomas $(1976,1977)$ presented evidence that abundant nitrate fertilization of wheat in the field increases the ratio of photorespiration to photosynthesis, suggesting modifications to photorespiratory metabolism. Nitrate reductase activity showed greater change with nitrate nutrition and temperature than did RuBPc-o activity or that of other photosynthetic enzymes, suggesting that the balance between nitrate reduction and assimilation might be varied by environmental conditions and provide a mechanism by which metabolism and cell composition respond to differences in nitrate supply and temperature (Lawlor et al., 1987a).

If the efficiency of the photosynthetic system, including carbon and nitrogen assimilation, is to be improved, it is essential that we understand the factors regulating the amounts of components, efficiencies of light harvesting and of the enzymatic 'dark' processes of photosynthesis and photorespiration, and the balance between these various processes (Farquhar and von Caemmerer, 1982). Studies are often restricted to particular metabolic processes, yet the agriculturally important feature is the production of the whole plant. To analyse the mechanisms of plant response to nitrate nutrition and temperature we have measured photosynthesis, stomatal conductance, photorespiration and photosystem electron transport of the 3rd leaf of wheat; they are related to changes in leaf composition, reported by Lawlor et al. $(1987 a)$, to understand the integration of metabolic and physiological processes and the effects of environment on the plant responses.

\section{MATERIALS AND METHODS \\ Growth conditions}

Plants of spring wheat (Triticum aestivum var. Kolibri) were grown as described in Lawlor et al. (1987a) with low or high $\left(4 \times\right.$ low) nitrate concentration $\left(-\mathrm{N}^{\mathrm{N}}\right.$ and $+\mathrm{N} ; 0.9$ and $4.0 \mathrm{mmol} \mathrm{NO}_{3}^{-}$ weekly per pot respectively) supplied in Hoagland's nutrient, at day/night temperature of $13 / 10^{\circ} \mathrm{C}$ (treatment $\mathrm{C}$ ) and $23 / 18^{\circ} \mathrm{C}$ (treatment $\mathrm{W}$ ) at $550 \mu \mathrm{mol}$ quanta photosynthetically active radiation $(P A R) \mathrm{m}^{-2} \mathrm{~s}^{-1}$ or, in other experiments, at either 350 or $600 \mu \mathrm{mol}$ quanta $\mathrm{m}^{-2} \mathrm{~s}^{-1}$.

Leaves were sampled $13,15,17,21$ and $24 \mathrm{~d}$ after sowing in the warm conditions and after 22, 26, 29,36 and $42 \mathrm{~d}$ in the cold. These times correspond to approximately equivalent physiological ages of the leaves, and to equivalent accumulated temperature above $0{ }^{\circ} \mathrm{C}$. In the text the leaf growth stages are referred to as expanding, almost mature, mature, ageing and early senescent.

\section{Measurement of net photosynthesis, photorespiration and $\mathrm{CO}_{2}$ compensation concentration}

Photosynthesis was measured in two gas exchange systems of different design. In one, net photosynthesis was measured on five detached leaf pieces (five pieces, $5.0 \mathrm{~cm}$ long, $c .10 \mathrm{~cm}^{2}$ ), standing with the cut ends in water, in an open flow gas stream without forced ventilation. The $P A R$ flux was 1000 $\mu \mathrm{mol}$ quanta $\mathrm{m}^{-2} \mathrm{~s}^{-1}$ from a tungsten-halogen lamp and air was supplied from commercial gas cylinders. Carbon dioxide exchange was measured in triplicate by infra-red gas analysis (Analytical Development Company, Hoddesdon, U.K.; model 225 Mk. II Analyser). Photorespiration was measured as $\mathrm{CO}_{2}$ efflux into $\mathrm{CO}_{2}$-free air. Temperature was regulated by circulating water from a water bath through a jacket surrounding the leaf chamber.

Photosynthesis was also measured in triplicate in an open gas exchange system, concomitant with water vapour exchange, on single attached leaves in a chamber with forced ventilation. Carbon 
dioxide and oxygen concentrations in the chamber atmosphere were controlled by a gas blender (Signal Instrument Co., Croydon, U.K.) and measured using an infra-red gas analysis (ADC Mk. III Analyser) and a paramagnetic oxygen analyser (Hartman and Braun, West Germany) respectively. Photon flux density from mercury vapour lamps was varied by neutral wire-mesh screens. Leaf temperature was measured by a fine wire thermocouple pressed to the lower surface and was regulated by adjusting the temperature of the chamber water jacket. The water vapour content of the air was controlled by saturating with water vapour and cooling to required dew point before warming to the required temperature, and was measured by humidity sensors (Vaisala, U.K.) before and after passage over the leaf, vapour pressure deficit was maintained at 0.8 to $1.0 \mathrm{kPa}$. Leaf areas, for calculation of photosynthetic rates, were determined by an automatic planimeter (Platon Industries, Australia). Both photosynthesis rate and stomatal conductance were calculated according to Farquhar and Sharkey (1982).

The response of net photosynthesis to partial pressure of $\mathrm{CO}_{2}\left(\right.$ ( $\mathrm{CO}_{2}$ response curves') was measured at $1000 \mu \mathrm{mol}$ quanta $\mathrm{m}^{-2} \mathrm{~s}^{-1}$, and at an $\mathrm{O}_{2}$ partial pressure of either 2.0 or $21 \mathrm{kPa}$. The response to photon flux ('light response curves') was measured at $90 \mathrm{~Pa} \mathrm{CO}_{2}$ partial pressure in 2.0 or $21 \mathrm{kPa} \mathrm{O}$. Carboxylation efficiency was derived from the initial slope of the $\mathrm{CO}_{2}$ response curves, and the quantum yield (photochemical efficiency) was calculated from the initial slope of the light response curves, after correction for reflection and transmission of radiant energy by the leaves derived from a integrating sphere (Applied Photophysics, U.K.).

Carbon dioxide compensation concentration of leaves was determined in triplicate from the $\mathrm{CO}_{2}$ response curves or from measurements made in a closed circuit system at constant temperature $\left(20^{\circ} \mathrm{C}\right)$ and light $\left(1200 \mu \mathrm{mol}\right.$ quanta $\left.\mathrm{m}^{-2} \mathrm{~s}^{-1}\right)$. Equilibrium in the closed system was reached from initial conditions of zero $\mathrm{CO}_{2}$ or from $c .40 \mathrm{~Pa} \mathrm{CO}_{2}$ and required 15 to $20 \mathrm{~min}$; leakage of $\mathrm{CO}_{2}$ into the closed system caused an increase in $\mathrm{CO}_{2}$ partial pressure of less than $0.1 \mathrm{~Pa} \mathrm{CO}_{2}$ in $10 \mathrm{~min}$.

\section{Measurement of gross photosynthesis and photorespiration using ${ }^{14} \mathrm{CO}_{2}$}

Assimilation of ${ }^{14} \mathrm{CO}_{2}$ was measured on attached leaves in the ventilated leaf chamber using ${ }^{14} \mathrm{CO}_{2}$ at constant specific activity, $14.3 \mathrm{kBq} \mu \mathrm{mol}^{-1} \mathrm{CO}_{2}$, in air $(21 \mathrm{kPa} \mathrm{O}, 79 \mathrm{kPa} \mathrm{N}$ ) from a gas cylinder. Gross photosynthesis was calculated (Ludwig and Canvin, 1971) from measurements of ${ }^{14} \mathrm{CO}_{2}$ depletion made with a $20 \mathrm{~cm}^{3}$ ionisation chamber and electrometer (Varian Associates) with the switching system described by Lawlor, Mahon, and Fock (1977). Measurements were taken after $15 \mathrm{~s}$ exposure to ${ }^{14} \mathrm{CO}_{2}$ under steady-state $\mathrm{CO}_{2}$ partial pressure and with a steady rate of net assimilation. After assimilation of ${ }^{14} \mathrm{CO}_{2}$, leaves were removed from the chamber and frozen in liquid nitrogen within $2 \mathrm{~s}$.

\section{Measurement of oxygen uptake and evolution}

Oxygen exchange of cut sections of leaves grown in 350 or $600 \mu \mathrm{mol}$ quanta $P A R \mathrm{~m}^{-2} \mathrm{~s}^{-1}$ was measured by polarographic oxygen electrode (Hansatech Limited) at saturating $\mathrm{CO}_{2}$ concentrations and $21-22 \mathrm{kPaO} \mathrm{O}_{2}$ in the atmosphere.

\section{Photosystem assay}

Activities of photosystems I and photosystems I + II were measured on thylakoid fragments prepared by the method of Powles and Critchley (1980) using a polarographic oxygen electrode at $20^{\circ} \mathrm{C}$ with chlorophyll concentration of 300 to $400 \mu \mathrm{g} \mathrm{cm}^{-3}$ of solution. PS I was assayed by measuring the rate of $\mathrm{O}_{2}$ consumption, with ascorbate/DCPIP as electron donor and methyl viologen (MV) as electron acceptor in an assay medium containing $30 \mathrm{~mol} \mathrm{~m}^{-3}$ orthophosphate buffer (pH 8.0), 10 mol m$~_{-3} \mathrm{MgCl}_{2}, 1.0 \mathrm{~mol} \mathrm{~m}^{-3}$ ascorbate, $0.1 \mathrm{~mol} \mathrm{~m}^{-3}$ DCPIP, $0.1 \mathrm{~mol} \mathrm{~m}^{-3} \mathrm{MV}$ and $2.5 \mathrm{~mol} \mathrm{~m}^{-3}$ $\mathrm{NH}_{4} \mathrm{Cl}$ as uncoupler. Photosystem I plus II in combination was assayed by measuring $\mathrm{O}_{2}$ evolution linked to potassium ferricyanide reduction in a reaction mixture containing $50 \mathrm{~mol} \mathrm{~m}^{-3} \mathrm{HEPES}(\mathrm{pH}$ 7.6), $1.0 \mathrm{~mol} \mathrm{~m}^{-3} \mathrm{MgCl}_{2}, 1.0 \mathrm{~mol} \mathrm{~m}^{-3}$ EDTA and $1.5 \mathrm{~mol} \mathrm{~m}^{-3} \mathrm{~K}_{3} \mathrm{Fe}(\mathrm{CN})_{6}$. Actinic light, from a quartz-halogen lamp, was at saturating photon flux $\left(1000 \mu \mathrm{mol}\right.$ quanta $\left.\mathrm{m}^{-2} \mathrm{~s}^{-1}\right)$. Two determinations were made on two occasions on groups of plants from each treatment at equivalent physiological stages of development.

Chlorophyll was measured by the method of Arnon (1949) in acetone extracts of leaves or homogenates from the photosystem assay. Measurements of RuBP carboxylase-oxygenase amount and activity and soluble protein were described by Lawlor et al. (1987a). 


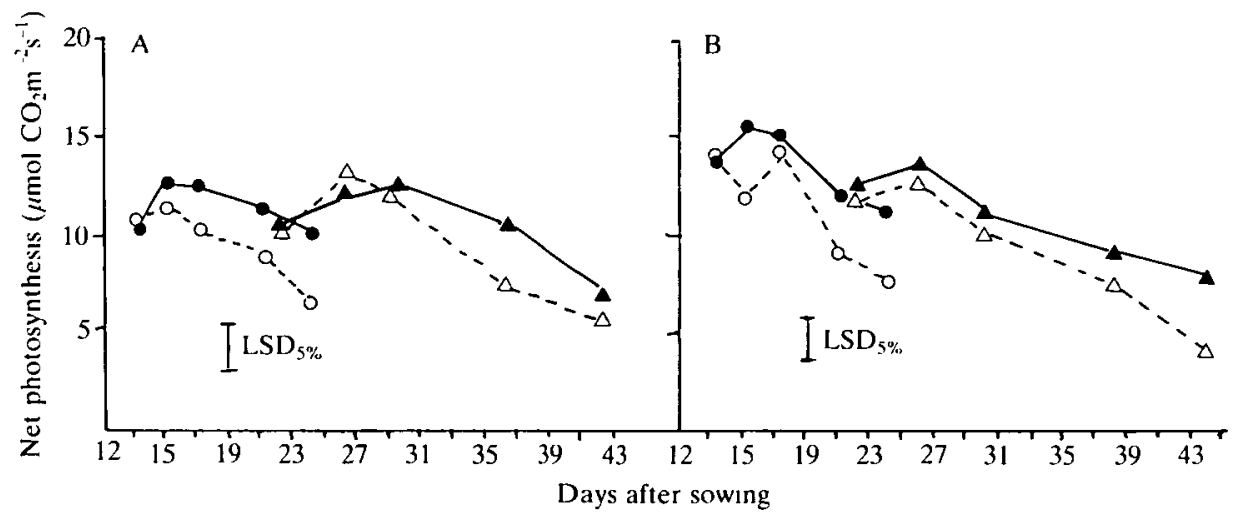

FIG. 1. Net photosynthesis related to age of the 3rd leaf of wheat grown at $13 / 10^{\circ} \mathrm{C}$ (day/night temperatures) $\mathrm{C}$, and $23 / 18^{\circ} \mathrm{C}, \mathrm{W}$, and with low nitrate $(-\mathrm{N})$ or high $(4 \times$ the low amount of nitrate: $+\mathrm{N}$ ). Measurements at $13{ }^{\circ} \mathrm{C}$ (Fig. la) and $23^{\circ} \mathrm{C}$ (Fig. lb); $33 \mathrm{~Pa} \mathrm{CO}_{2}, 21 \mathrm{kPa} \mathrm{O}, 1000 \mu \mathrm{mol}$ quanta $(P A R) \mathrm{m}^{-2} \mathrm{~s}^{-1}$ photon flux density. Bar represents least significant difference $(P=5 \%)$.

$$
\mathrm{C}-\mathrm{N}---\mathbf{\Delta -}--, \mathrm{C}+\mathrm{N} \longrightarrow \mathbf{-}-\mathrm{W}-\mathrm{N}---0--, \mathrm{W}+\mathrm{N} \longrightarrow
$$

\section{RESULTS}

Net photosynthesis and $\mathrm{CO}_{2}$ response

Rates of $P_{\text {net }}$ were measured in unstirred leaf chambers at two temperatures corresponding to the day-time growing temperature. Leaves grown under warmer conditions had higher $P_{\text {net }}$ (Fig. 1a, b) than those grown in the cooler temperature when measured at $23{ }^{\circ} \mathrm{C}$, but when measured at $13{ }^{\circ} \mathrm{C}$ there was little difference. Expanding leaves from all growth conditions had very similar rates of assimilation, and nitrogen supply had little effect. Mature leaves grown with additional nitrate had, on average, $15 \%$ higher rates of assimilation than those grown with low nitrate. At early senescence, $P_{\text {net }}$ of leaves grown with extra nitrate decreased by about $25 \%$ in warm and $44 \%$ in the cool growth conditions respectively compared to the rate at maturity (and averaged over measurement temperature), and decreased without additional nitrogen by $47 \%$ and $67 \%$ in warm and cool growth conditions respectively. Attached leaves, in ventilated leaf chambers at $20^{\circ} \mathrm{C}$, had higher rates of assimilation when young (Fig. 2) than those measured in unstirred chambers at similar irradiance, but treatment effects were similar. $P_{\text {net }}$ ranged from 26 to $18 \mu \mathrm{mol} \mathrm{CO}_{2}$ $\mathrm{m}^{-2} \mathrm{~s}^{-1}$ at maximum leaf expansion in the $\mathrm{W}+\mathrm{N}$ and $\mathrm{C}-\mathrm{N}$ treatments respectively, but decreased to 11.0 and $8.0 \mu \mathrm{mol} \mathrm{CO} \mathrm{Cm}^{-2} \mathrm{~s}^{-1}$ in the same treatments at early senescence. Assimilation at saturating $\mathrm{CO}_{2}$ (Fig. 2) was about $50 \%$ and $70 \%$ greater than in normal air (32 $\mathrm{Pa} \mathrm{CO}_{2}$ ) for leaves grown in warm and cool conditions respectively and was greater with additional nitrate, but independent of growth temperature.

Net photosynthesis was determined in the ventilated chamber at a range of $\mathrm{CO}_{2}$ partial pressures and $1000 \mu \mathrm{mol}$ quanta $\mathrm{m}^{-2} \mathrm{~s}^{-1}$ at $20^{\circ} \mathrm{C}$ to analyse the response of assimilation to internal $\mathrm{CO}_{2}$ pressure. In mature leaves grown with additional nitrate, $P_{\mathrm{n}}$ saturated at approximately $35 \mu \mathrm{mol} \mathrm{CO} \mathrm{m}^{-2} \mathrm{~s}^{-1}$ when the internal $\mathrm{CO}_{2}$ pressure was $c$. $40 \mathrm{~Pa}$, and there was little difference between the warm or cold grown plants. Leaves from warmgrown plants without additional $\mathrm{N}$ had a smaller maximum rate of assimilation than those grown with extra $\mathrm{N}\left(32 \mathrm{cf} .34 \mu \mathrm{mol} \mathrm{m} \mathrm{m}^{-2} \mathrm{~s}^{-1}\right.$ ) but smaller $\left(25 \mathrm{cf} .32 \mu \mathrm{mol} \mathrm{m} \mathrm{m}^{-2} \mathrm{~s}^{-1}\right.$ ) when grown in the cold. The rate of assimilation per unit of internal $\mathrm{CO}_{2}$ partial pressure and the maximum rate of photosynthesis decreased as the leaves aged in all treatments but remained greater in leaves from plants grown with extra nitrate. $P_{\max }$ decreased rapidly 
particularly in warm conditions. By comparison net photosynthesis measured in $32 \mathrm{~Pa} \mathrm{CO}_{2}$ decreased less rapidly.

Carboxylation efficiency of young leaves grown at warm temperature (measured at $15 \mathrm{~d}$ ) was greater than of plants grown in the cold (measured at $25 \mathrm{~d}$ ) both with and without additional nitrate $(\mathrm{W}+\mathrm{N} 1.62 ; \mathrm{W}-\mathrm{N} 1.50 ; \mathrm{C}+\mathrm{N} 1.55 ; \mathrm{C}-\mathrm{N} \mathrm{1.38}$; (1.s.d. 0.105$) \mu \mathrm{mol}$ $\left.\mathrm{CO}_{2} \mathrm{~m}^{-2} \mathrm{~s}^{-1} \mathrm{~Pa}^{-1}\right)$. As leaves aged the carboxylation efficiency decreased rapidly in all treatments; the rate of decrease per day was slightly greater for leaves grown in warm (measured at $25 \mathrm{~d}$ ) than cool (measured at $\mathbf{4 0} \mathrm{d}$ ) conditions and without compared to with extra nitrate $\left(\mathrm{W}+\mathrm{N} 0.80 ; \mathrm{W}-\mathrm{N} 0.79 ; \mathrm{C}+\mathrm{N} 0.40 ; \mathrm{C}-\mathrm{N} 0.45 \mu \mathrm{mol} \mathrm{CO}_{2} \mathrm{~m}^{-2} \mathrm{~s}^{-1} \mathrm{~Pa}^{-1}\right)$.

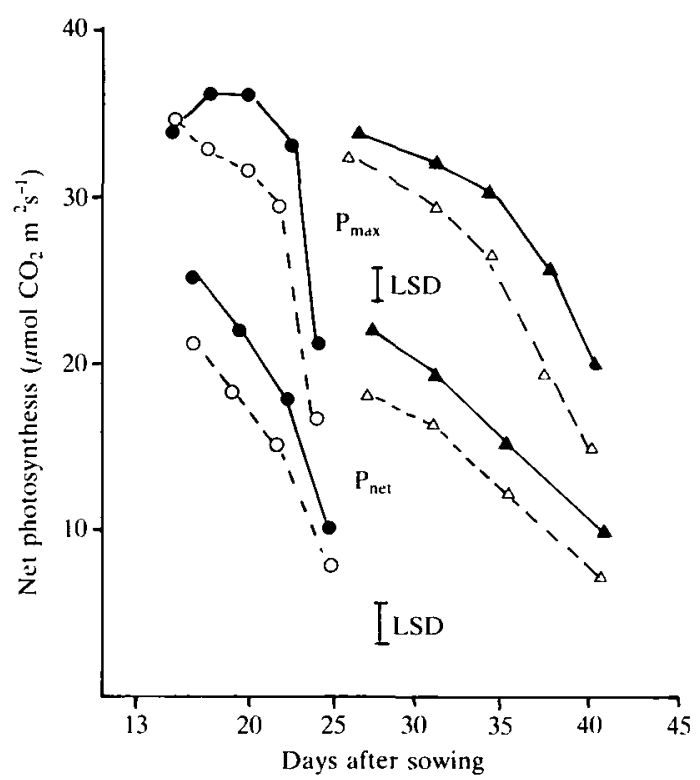

FIG. 2. Maximum photosynthetic rate $\left(P_{\max }\right)$ at saturating $\mathrm{CO}_{2}(90 \mathrm{~Pa})$, compared with the rate at 32 $\mathrm{Pa} \mathrm{CO},\left(\mathrm{P}_{\mathrm{n}}\right)$, and $1000 \mu \mathrm{mol}$ quanta $\mathrm{m}^{-2} \mathrm{~s}^{-1}$ in $21 \mathrm{kPa} \mathrm{O}_{2}, 20^{\circ} \mathrm{C}$ for leaves of wheat grown under $\mathrm{C}-\mathrm{N}, \mathrm{C}+\mathrm{N}, \mathrm{W}-\mathrm{N}$ and $\mathrm{W}+\mathrm{N}$ conditions. Bar represents least significant difference $(P=5 \%)$.

\section{Photosynthetic light response, photochemical efficiency and stomatal conductance}

Assimilation by young leaves grown in warm conditions (Fig. $3 a$ ) increased with illumination from zero up to $1500 \mu \mathrm{mol}$ quanta $\mathrm{m}^{-2} \mathrm{~s}^{-1}$ although the increase per unit of $P A R$ was much less above $\sim 500 \mu \mathrm{mol}$ quanta $\mathrm{m}^{-2} \mathrm{~s}^{-1}$. Maximum rate of assimilation was smaller with low nitrate, and with age $P_{\max }$ decreased, rather more with deficient nitrogen. Leaves of cold-grown plants (Fig. $3 \mathrm{~b}$ ) responded to increasing photon flux similar to warmgrown up to $\sim 1000 \mu \mathrm{mol}$ quanta $\mathrm{m}^{-2} \mathrm{~s}^{-1}$ but with brighter light their assimilation rate decreased.

Stomatal conductance of young leaves as a function of photon flux (Fig. 4a) was little affected by growth conditions but (Fig. 4b) conductance of older, cold-grown leaves decreased markedly in both nitrate treatments. As leaves aged, conductance (Fig. 4b) measured at $1000 \mu \mathrm{mol}$ quanta $\mathrm{m}^{-2} \mathrm{~s}^{-1}$ (i.e. below the threshold for stomatal closure in cold-grown plants) decreased more rapidly in warm than in cold conditions. The absolute decrease in conductance was greatest with nitrate deficiency in cold conditions.

The photochemical efficiency ( $\mathrm{mol} \mathrm{CO}_{2} / \mathrm{mol}$ quanta), calculated from the initial slope of 
the light response curve, and measured in both warm and cool conditions, was similar in young leaves from warm (16-d-old) and cool (24-d-old) conditions ( W + N 0.042; W - N $0.044 ; C+N 0.040 ; C-N 0.039$; s.e.d. 0.005). It decreased with leaf age in all treatments, the decrease was somewhat greater with nitrate deficiency but differences were small and only significant in the case of the cold grown plants; at $25 \mathrm{~d}$ and $40 \mathrm{~d}$ in cool and warm conditions the values were $\mathrm{W}+\mathrm{N}, 0.028 ; \mathrm{W}-\mathrm{N}, 0.028 ; \mathrm{C}+\mathrm{N}, 0.029$ and $\mathrm{C}-\mathrm{N}, 0.020$.

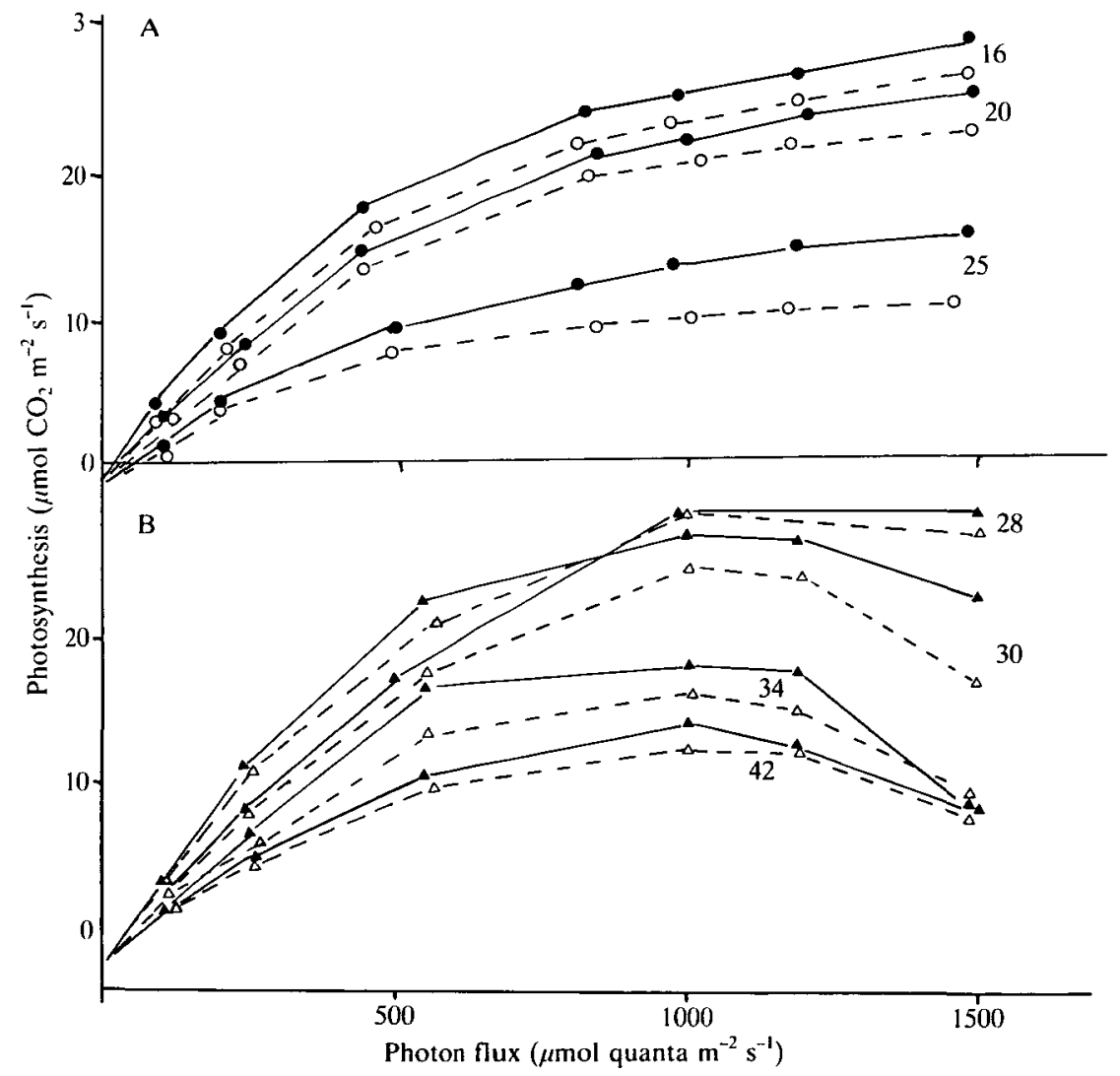

FIG. 3. Response of photosynthesis to photon flux, for the 3rd leaf of wheat grown under conditions described in legend to Fig. 1. Measurements at $32 \mathrm{~Pa} \mathrm{CO}_{2}, 21 \mathrm{kPa} \mathrm{O}, 20^{\circ} \mathrm{C}$. (A) $\mathrm{W}+\mathrm{N}, \mathrm{W}-\mathrm{N}$ plants, 16, 20 and 25-d-old. (B) $C+N, C-N$ plants 28,30 and 42-d-old. Typical responses for single leaves.

\section{Effects of the oxygen partial pressure}

Assimilation was compared in 2 and $21 \mathrm{kPa} \mathrm{O}$, at $23{ }^{\circ} \mathrm{C}$ and $13{ }^{\circ} \mathrm{C}$ (Table 1). Decreasing oxygen partial pressure increased photochemical efficiency by $32 \%$ when measured at $23{ }^{\circ} \mathrm{C}$ and $24 \%$ at $13{ }^{\circ} \mathrm{C}$; photochemical efficiency was not significantly affected by nitrate supply and was greatest in warm grown plants measured at $23{ }^{\circ} \mathrm{C}$ in $2.0 \mathrm{kPa} \mathrm{O}$. The effect of decreasing $\mathrm{O}_{2}$ concentration on $\mathrm{CO}_{2}$ exchange was measured in the ventilated chamber at $1000 \mu \mathrm{mol}$ quanta $\mathrm{m}^{-2} \mathrm{~s}^{-1}$ and $32 \mathrm{~Pa} \mathrm{CO}_{2}$. Measured at $23{ }^{\circ} \mathrm{C}$ (Table 2) photosynthesis increased in low $\mathrm{O}_{2}$ by between $28 \%$ and $35 \%$; measured at $13{ }^{\circ} \mathrm{C}$ the increase in assimilation was between $12 \%$ and $28 \%$. The smallest difference was in $\mathrm{C}-\mathrm{N}$ grown plants and largest in the warm grown plants. However, there was no significant difference, averaged over all measurements, between plants grown with different nitrate supply or temperature. 


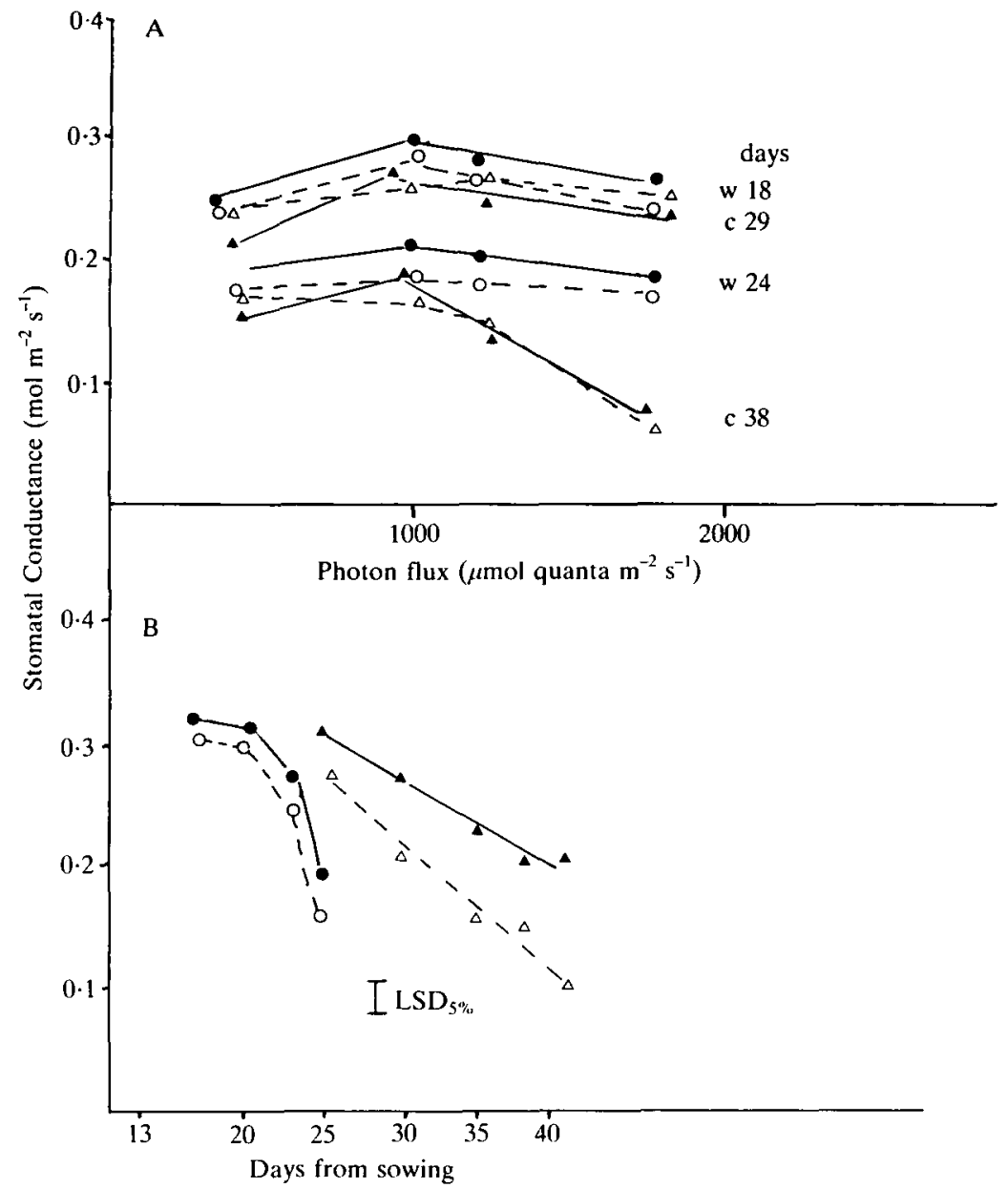

FIG. 4. Stomatal conductance of wheat leaves of $(A)$ different ages (given on figure) in relation to photon flux and (B) stomatal conductance at $1000 \mu \mathrm{mol}$ quanta $\mathrm{m}^{-2} \mathrm{~s}^{-1}$ with leaves of different ages; treatments described in legend to Fig. 1.

TABLE 1. Photochemical efficiency ( $\mathrm{mol}^{\circ} \mathrm{CO}_{2} \mathrm{~mol}_{\text {absorbed quanta }}{ }^{-1}$ ) for wheat leaves grown at two temperatures $\left(13{ }^{\circ} \mathrm{C}\right.$ and $\left.23^{\circ} \mathrm{C}\right)$ and with low or high nitrate supply and measured at $13{ }^{\circ} \mathrm{C}$ and $23^{\circ} \mathrm{C}$ and in 2.0 and $21 \mathrm{kPa} \mathrm{O} ; \%$ increase in efficiency is $(2.0 \mathrm{kPa} / 21 \mathrm{kPa})$ $\times 100$

\begin{tabular}{|c|c|c|c|c|c|c|}
\hline \multirow{3}{*}{$\begin{array}{l}\text { Measurement } \\
\text { temperature }\end{array}$} & \multirow[t]{3}{*}{$\mathrm{O}_{2}(\mathrm{kPa})$} & \multicolumn{4}{|c|}{ Growth temperature } & \multirow{3}{*}{$\begin{array}{l}\text { Standard } \\
\text { error of } \\
\text { difference }\end{array}$} \\
\hline & & \multicolumn{2}{|c|}{$13 / 10^{\circ} \mathrm{C}$} & \multicolumn{2}{|c|}{$23 / 18^{\circ} \mathrm{C}$} & \\
\hline & & $\begin{array}{l}\mathrm{N} \\
(24-28-\end{array}$ & $\begin{array}{c}+N \\
d-\text {-old) }\end{array}$ & $\begin{array}{l}N \\
(16-18-\end{array}$ & $\begin{array}{c}+\mathrm{N} \\
\mathrm{d} \text {-old })\end{array}$ & \\
\hline \multirow[t]{2}{*}{$23^{\circ} \mathrm{C}$} & $\begin{array}{r}2 \\
21\end{array}$ & $\begin{array}{l}0.047 \\
0.038\end{array}$ & $\begin{array}{l}0.052 \\
0.041\end{array}$ & $\begin{array}{l}0.058 \\
0.043\end{array}$ & $\begin{array}{l}0.058 \\
0.041\end{array}$ & $\begin{array}{l}0.007 \\
0.005\end{array}$ \\
\hline & $\%$ Increase & 24 & 27 & 35 & 41 & \\
\hline \multirow[t]{2}{*}{$13^{\circ} \mathrm{C}$} & $\begin{array}{r}2 \\
21\end{array}$ & $\begin{array}{l}0.050 \\
0.037\end{array}$ & $\begin{array}{l}0.053 \\
0.041\end{array}$ & $\begin{array}{l}0.050 \\
0.044\end{array}$ & $\begin{array}{l}0.051 \\
0.042\end{array}$ & $\begin{array}{l}0.006 \\
0.005\end{array}$ \\
\hline & $\%$ Increase & 35 & 29 & 14 & 21 & \\
\hline
\end{tabular}


TABLE 2. Photosynthesis and photorespiration $\left(\mu \mathrm{mol} \mathrm{m}^{-2} \mathrm{~s}^{-1}\right)$ measured at $1000 \mu \mathrm{mol}$ quanta $\mathrm{PARm} \mathrm{m}^{-2} \mathrm{~s}^{-1}, 32 \mathrm{PaCO}_{2}$ and at $2 \cdot 0\left(\mathrm{P}_{2}\right)$ and $21 \mathrm{kPaO} \mathrm{O}_{2}\left(P_{21}\right)$ and at two temperatures. Plants grown in two temperatures and with two nitrate concentrations. Photorespiration $(P R)$ calculated as difference $P_{2}-P_{21}$ and $P R \%$ as $100\left(P_{2}-P_{21}\right) / P_{21}$

\begin{tabular}{|c|c|c|c|c|c|c|}
\hline \multirow{3}{*}{$\begin{array}{l}\text { Measurement } \\
\text { temperature }\end{array}$} & \multirow{3}{*}{$\mathrm{O}_{2}(\mathrm{kPa})$} & \multicolumn{4}{|c|}{ Growth temperature } & \multirow{3}{*}{$\begin{array}{l}\text { Standard } \\
\text { error of } \\
\text { difference }\end{array}$} \\
\hline & & \multicolumn{2}{|c|}{$13 / 10^{\circ} \mathrm{C}$} & \multicolumn{2}{|c|}{$23 / 10^{\circ} \mathrm{C}$} & \\
\hline & & $\mathbf{N}$ & $+\mathrm{N}$ & $\mathbf{N}$ & $+\mathrm{N}$ & \\
\hline \multirow[t]{2}{*}{$23^{\circ} \mathrm{C}$} & $\begin{array}{l}P_{2} \\
P_{21}\end{array}$ & $\begin{array}{l}23 \\
18\end{array}$ & $\begin{array}{l}28 \\
21\end{array}$ & $\begin{array}{l}23 \\
17\end{array}$ & $\begin{array}{l}28 \\
21\end{array}$ & $\begin{array}{l}3 \cdot 19 \\
2 \cdot 90\end{array}$ \\
\hline & $\begin{array}{l}\mathrm{PR} \\
\mathrm{PR} \%\end{array}$ & $\begin{array}{r}5 \\
28\end{array}$ & $\begin{array}{r}7 \\
33\end{array}$ & $\begin{array}{r}6 \\
35\end{array}$ & $\begin{array}{r}7 \\
33\end{array}$ & $\begin{array}{l}1.56 \\
-\end{array}$ \\
\hline \multirow[t]{2}{*}{$13^{\circ} \mathrm{C}$} & $\begin{array}{l}P_{2} \\
P_{21}\end{array}$ & $\begin{array}{l}19 \\
17\end{array}$ & $\begin{array}{l}22 \\
18\end{array}$ & $\begin{array}{l}22 \\
18\end{array}$ & $\begin{array}{l}24 \\
18\end{array}$ & $\begin{array}{l}2 \cdot 39 \\
2 \cdot 00\end{array}$ \\
\hline & $\begin{array}{l}\mathrm{PR} \\
\mathrm{PR} \%\end{array}$ & $\begin{array}{r}2 \\
12\end{array}$ & $\begin{array}{r}4 \\
22\end{array}$ & $\begin{array}{r}4 \\
22\end{array}$ & $\begin{array}{r}5 \\
28\end{array}$ & $\begin{array}{c}2 \cdot 20 \\
-\end{array}$ \\
\hline
\end{tabular}

Mean of 5 equivalent ages of plants.

\section{Photorespiration and $\mathrm{CO}_{2}$ compensation concentration}

Photorespiration of leaves was measured in unstirred chambers as $\mathrm{CO}_{2}$ efflux to $\mathrm{CO}_{2}$ free air, at $13{ }^{\circ} \mathrm{C}$ and at $23^{\circ} \mathrm{C}$, with $1000 \mu$ mol quanta $\mathrm{m}^{-2} \mathrm{~s}^{-1}$ and $21 \mathrm{kPa} \mathrm{O}_{2}$. Photorespiration was greater at $23^{\circ} \mathrm{C}$ than at $13{ }^{\circ} \mathrm{C}$ (Fig. 5) and in leaves grown with additional nitrate than without, particularly as the leaves aged. Cool growth temperature also decreased photorespiration compared to warm when measured at $23^{\circ} \mathrm{C}$. The ratio of photorespiration to net photosynthesis measured at $13{ }^{\circ} \mathrm{C}$ was approximately $14 \%$ and was similar in young

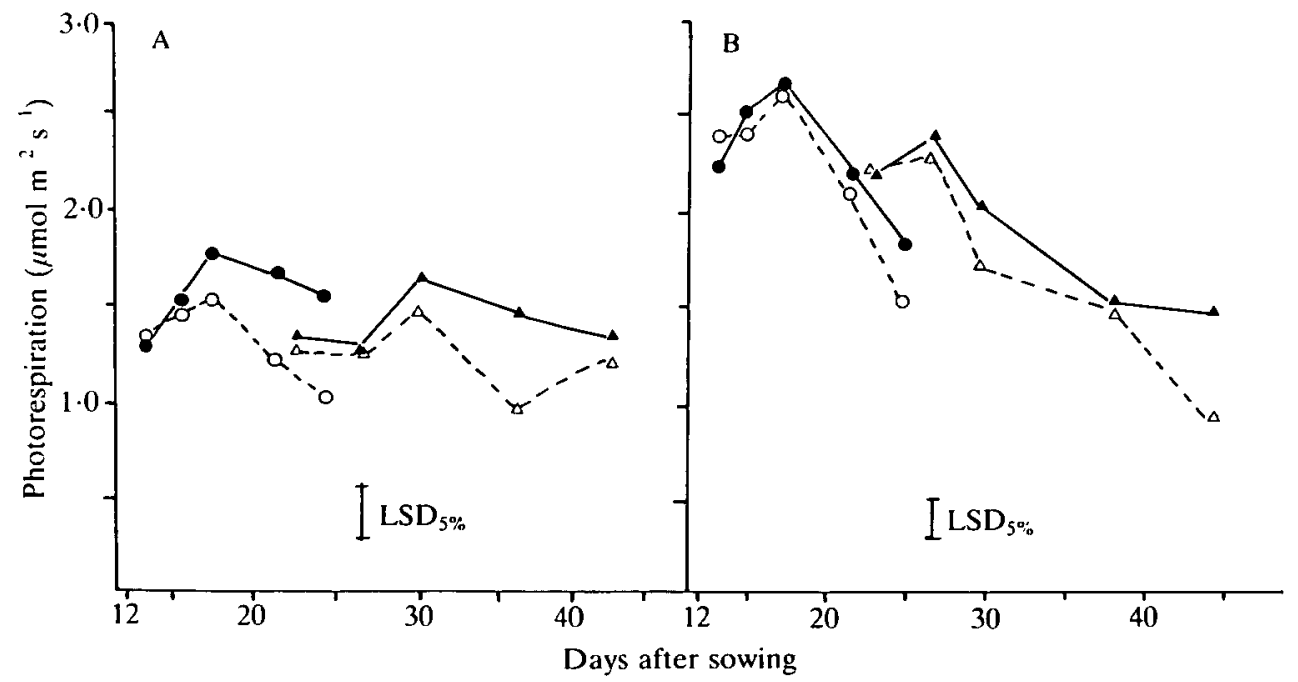

FIG. 5. Photorespiratory $\mathrm{CO}_{2}$ evolution related to the age of wheat leaves grown under different temperature and nitrate supply, measured at $(\mathrm{A}) 13^{\circ} \mathrm{C}$ and $(\mathrm{B}) 23{ }^{\circ} \mathrm{C}$, by $\mathrm{CO}_{2}$ efflux into $\mathrm{CO}_{2}$-free air $\left(21 \mathrm{kPa} \mathrm{O}, 1000 \mu \mathrm{mol}\right.$ quanta $\left.\mathrm{m}^{-2} \mathrm{~s}^{-1}\right)$. Bars represent least significant differences $(P=5 \%)$. 


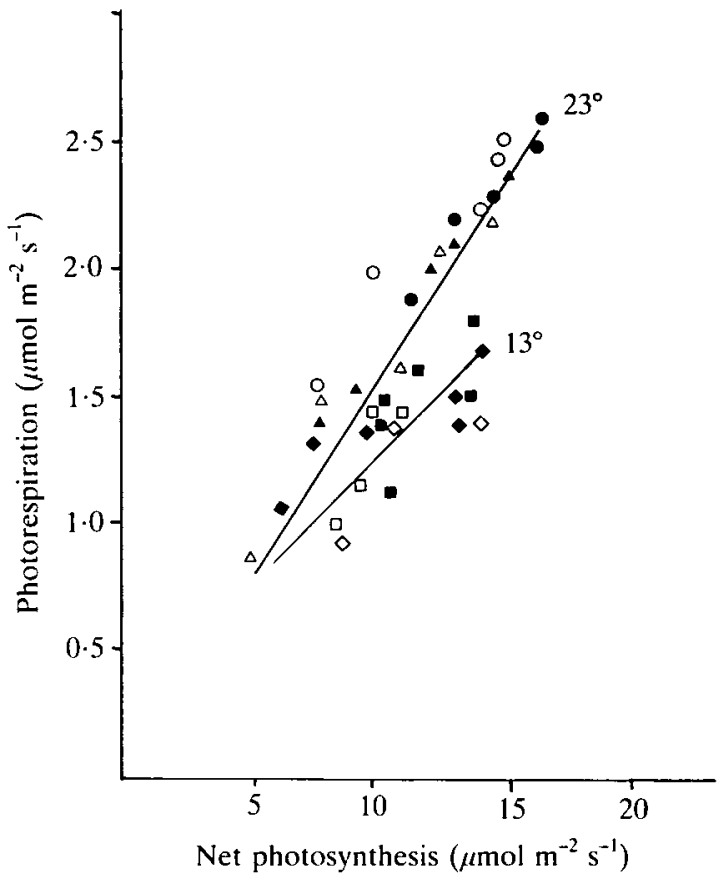

FIG. 6. Photorespiration in relation to net photosynthesis for the third leaf of wheat, grown under conditions described in legend to Fig. 1. Measurements made at $13{ }^{\circ} \mathrm{C}$ or $23^{\circ} \mathrm{C}$.

and old leaves on both $+\mathrm{N}$ and $-\mathrm{N}$ treatments. Photorespiration of leaves measured at $23^{\circ} \mathrm{C}$, was $c .17 \%$ of net photosynthesis in all treatments and did not change significantly with leaf age. Photorespiration measured at a particular temperature, was proportional to net photosynthesis for plants grown under all conditions (Fig. 6).

The compensation concentration of mature leaves (Table 3) was greater when measured at $23{ }^{\circ} \mathrm{C}$ than at $13{ }^{\circ} \mathrm{C}$ but did not differ significantly with growth conditions. Compensation concentration estimated from the $\mathrm{CO}_{2}$ response curves was not significantly different between treatments, although, as the leaves aged, it increased in the low nitrate treatments more than in the high.

TA BLE 3. Carbon dioxide compensation concentration $(\mathrm{Pa})$ of detached wheat leaves meas-

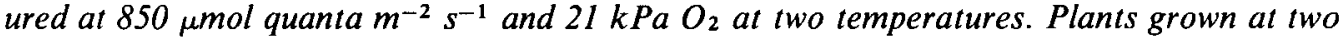
temperatures and at two levels of nitrate supply

\begin{tabular}{|c|c|c|c|c|c|}
\hline \multirow{3}{*}{$\begin{array}{l}\text { Measurement } \\
\text { temperature }\end{array}$} & \multicolumn{4}{|c|}{ Growth temperature } & \multirow{3}{*}{$\begin{array}{l}\text { Standard } \\
\text { error of } \\
\text { difference }\end{array}$} \\
\hline & \multicolumn{2}{|c|}{$13 / 10^{\circ} \mathrm{C}$} & \multicolumn{2}{|c|}{$23 / 18^{\circ} \mathrm{C}$} & \\
\hline & $\mathbf{N}$ & $+N$ & $\mathbf{N}$ & $+N$ & \\
\hline $23^{\circ} \mathrm{C}$ & 3.90 & $3 \cdot 73$ & $4 \cdot 06$ & $4 \cdot 01$ & $0 \cdot 12$ \\
\hline $13^{\circ} \mathrm{C}$ & $2 \cdot 90$ & $3 \cdot 40$ & $3 \cdot 24$ & 3.01 & $0 \cdot 14$ \\
\hline
\end{tabular}

Average of 5 measurements. 
The difference in photosynthesis between 21 and $2.0 \mathrm{kPa} \mathrm{O}_{2}$ shows the potential rate of assimilation in the absence of photorespiration. Assimilation in $2.0 \mathrm{kPa} \mathrm{O} 2$ was greater than that in air by approximately $32 \%$ (Table 2 ); this percentage increased slightly as leaves aged and was slightly (but not significantly) higher in low nitrate grown leaves.

Photorespiration was also estimated as the differences between net photosynthesis and calculated gross photosynthesis measured during steady-state photosynthesis $15 \mathrm{~s}$ after exposure to ${ }^{14} \mathrm{CO}_{2}$. The ratio of photorespiration to photosynthesis at $20{ }^{\circ} \mathrm{C}$ was $17 \%$ and $10 \%$ in $\mathrm{C}-\mathrm{N}$ and $\mathrm{C}+\mathrm{N}$ and $10 \%$ and $11 \%$ in $\mathrm{W}-\mathrm{N}$ and $\mathrm{W}+\mathrm{N}$ grown plants, but there was no significant difference between treatments. The mean values agreed with the estimates made by $\mathrm{CO}_{2}$ efflux to $\mathrm{CO}_{2}$-free air.

\section{Oxygen evolution by leaves}

Oxygen evolution was measured in saturating $\mathrm{CO}_{2}$ at $20^{\circ} \mathrm{C}$ as a function of photon flux on pieces of leaves grown in bright or dim light $\left(600\right.$ and $350 \mu \mathrm{mol}$ quanta $\mathrm{m}^{-2} \mathrm{~s}^{-1}$ respectively). In bright light ( $1500 \mu \mathrm{mol}$ quanta $\left.\mathrm{m}^{-2} \mathrm{~s}^{-1}\right), \mathrm{O}_{2}$ evolution was stimulated in leaves grown in bright compared to dim light $\left(27 \cdot 2\right.$ cf. $23 \cdot 3$; 1.s.d. $2.4 \mu \mathrm{mol} \mathrm{O}_{2} \mathrm{~m}^{-2} \mathrm{~s}^{-1}$ ) averaged over other treatments. Cool growth conditions increased $\mathrm{O}_{2}$ production $(28.8 \mathrm{cf}$. $\left.21.8 \mu \mathrm{mol} \mathrm{O}_{2} \mathrm{~m}^{-2} \mathrm{~s}^{-1}\right)$ with greater photochemical efficiency $(0.048 \mathrm{cf} .0 .038 ; 1$. s.d. 0.008 mol $\mathrm{O}_{2}$ mol-1 $^{-1}$ quanta). Additional nitrate supply increased $\mathrm{O}_{2}$ evolution slightly in all

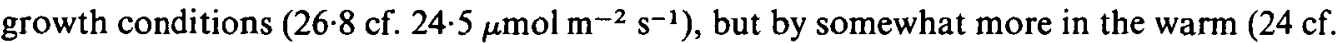
$21 \mu \mathrm{mol} \mathrm{O} \mathrm{O}_{2}^{-2} \mathrm{~s}^{-1}$ ) than in the cold (30 cf. $27.5 \mu \mathrm{mol} \mathrm{O} \mathrm{m}^{-2} \mathrm{~s}^{-1}$ ). Efficiency did not increase significantly with additional nitrate, $0.050 \mathrm{cf} .0 .045$ in the cold and $0.039 \mathrm{cf} .0 .037$ in the warm.

\section{Chlorophyll content and photosystem activity}

Chlorophyll a and b content per unit leaf area was greatest (Table 4) in leaves grown at low temperature with additional $\mathrm{N}$ and in bright light. However, the chlorophyll $\mathrm{a} / \mathrm{b}$ ratio was not significantly affected by illumination, temperature or additional nitrate. In other experiments the chl a/b ratio was 3.6 in plants from dim light and 3.2 from plants in

TA BLE 4. Photosystem activity in wheat leaves grown under high and low nitrate supply, two temperatures and at two photon fluxes. s.e.d. is standard error of difference

\begin{tabular}{|c|c|c|c|c|c|c|c|c|c|}
\hline \multirow{3}{*}{$\begin{array}{l}\text { Light } \\
\text { Temperature } \\
\text { Nitrate }\end{array}$} & \multicolumn{4}{|c|}{$350 \mu \mathrm{mol}$ quanta $\mathrm{m}^{-2} \mathrm{~s}^{-1}$} & \multicolumn{4}{|c|}{$650 \mu \mathrm{mol}$ quanta $\mathrm{m}^{-2} \mathrm{~s}^{-1}$} & \multirow[t]{3}{*}{ s.e.d. } \\
\hline & \multicolumn{2}{|c|}{$13 / 10^{\circ} \mathrm{C}$} & \multicolumn{2}{|c|}{$23 / 18^{\circ} \mathrm{C}$} & \multicolumn{2}{|c|}{$13 / 10^{\circ} \mathrm{C}$} & \multicolumn{2}{|c|}{$23 / 18^{\circ} \mathrm{C}$} & \\
\hline & $\mathbf{N}$ & $+N$ & $\mathrm{~N}$ & $+\mathrm{N}$ & $\mathbf{N}$ & $+N$ & $\mathbf{N}$ & $+\mathrm{N}$ & \\
\hline $\begin{array}{l}\text { PSI }\left(\mathrm{nmol} \mathrm{O}_{2}\right. \\
\left.\mathrm{mg}^{-1} \mathrm{chl} \mathrm{s}^{-1}\right)\end{array}$ & $35 \cdot 5$ & $42 \cdot 5$ & $44 \cdot 2$ & $38 \cdot 8$ & $40 \cdot 5$ & $29 \cdot 4$ & $39 \cdot 4$ & $32 \cdot 4$ & $3 \cdot 5$ \\
\hline $\begin{array}{l}\text { PSI }\left(\mu \mathrm{mol} \mathrm{O}_{2}\right. \\
\left.\mathrm{m}^{-2} \mathrm{~s}^{-1}\right)\end{array}$ & $17 \cdot 4$ & 23.5 & $16 \cdot 8$ & $18 \cdot 4$ & $21 \cdot 0$ & $18 \cdot 5$ & $14 \cdot 9$ & $16 \cdot 2$ & $4 \cdot 0$ \\
\hline $\begin{array}{c}\mathrm{PSI}+\mathrm{II}\left(\mathrm{nmol} \mathrm{O} \mathrm{O}_{2}\right. \\
\left.\mathrm{mg}^{-1} \mathrm{chl} \mathrm{s}^{-1}\right)\end{array}$ & $12 \cdot 4$ & 10.9 & $12 \cdot 9$ & $12 \cdot 0$ & $17 \cdot 8$ & $15 \cdot 1$ & $11 \cdot 1$ & $13 \cdot 3$ & $1 \cdot 1$ \\
\hline $\begin{array}{l}\mathrm{PSI}+\mathrm{II}\left(\mu \mathrm{mol} \mathrm{O} \mathrm{O}_{2}\right. \\
\left.\mathrm{m}^{-2} \mathrm{~s}^{-1}\right)\end{array}$ & $5 \cdot 9$ & 6.0 & 4.9 & $5 \cdot 7$ & $9 \cdot 2$ & $9 \cdot 5$ & $4 \cdot 0$ & $6 \cdot 7$ & $2 \cdot 8$ \\
\hline Chl $a+b\left(g^{-2}\right)$ & 0.48 & 0.55 & 0.38 & 0.47 & 0.52 & 0.63 & 0.36 & 0.50 & 0.03 \\
\hline $\mathrm{Chl} \mathrm{a} / \mathrm{b}$ ratio & $3 \cdot 5$ & $3 \cdot 2$ & $3 \cdot 5$ & $3 \cdot 4$ & $3 \cdot 3$ & $3 \cdot 5$ & 3.4 & $3 \cdot 3$ & 0.07 \\
\hline
\end{tabular}


bright light. Photosystem I activity per unit of chlorophyll (Table 4), was greatest in leaves grown in low light $\mathbf{W}-\mathbf{N}$ conditions; lowest activity was with bright light in $\mathrm{C}+\mathrm{N}$ growth conditions. On a leaf area basis, PSI activity was slightly greater with additional $N$, in the cold and in dim light. Photosystem I + II activity per unit of chlorophyll, with ferricyanide as acceptor, was greatest with bright light in cold conditions particularly with low N (Table 4). PS I + II activity per unit leaf area was somewhat larger in plants grown in bright light particularly in cool growth conditions and additional nitrogen also increased it.

\section{DISCUSSION}

\section{Assimilation rate, carboxylation efficiency and RuBPc-o characteristics}

The methods of measuring gas exchange gave comparable results; in the ventilated leaf chamber, rates of net photosynthesis were greater than in the unventilated chamber under similar conditions, probably because of its larger boundary layer conductance. Net photosynthesis was greatest in leaves at maximum expansion and was slower when measured at $13{ }^{\circ} \mathrm{C}$ compared to $23{ }^{\circ} \mathrm{C}$, probably due to slower rates of enzymatic processes.

Assimilation and photorespiration are related to the amounts of protein and pigments and to the activity of enzymes described previously (Lawlor et al., 1987a). The rate of photosynthesis increased with increasing amount of soluble protein (Fig. 7a) up to c. $6.0 \mathrm{~g}$ $\mathrm{m}^{-2}$ and with chlorophyll (Fig. $7 \mathrm{~b}$ ) up to $0.4 \mathrm{~g} \mathrm{~m}^{-2}$, when averaged over different leaf ages and conditions. At greater amounts of protein, assimilation was nearly constant and, with large chlorophyll amount, even decreased. Assimilation is, therefore, not limited by the amount of bulk pigment or protein at high concentration. As the amount of RuBPc-o forms an almost constant proportion of soluble protein, assimilation remained almost constant with increasing amounts of RuBPc-o in excess of $\sim 3.0 \mathrm{~g} \mathrm{~m}^{-2}$, under all conditions of light, $\mathrm{NO}_{3}^{-}$and temperature, so the rate of $\mathrm{CO}_{2}$ assimilation per unit of RuBPc-o protein decreased from about $4.4 \mu \mathrm{mol} \mathrm{CO}_{2} \mathrm{~g}^{-1}$ protein s $\mathrm{s}^{-1}$ at $3.0 \mathrm{~g} \mathrm{RuBPc}-0$ protein $\mathrm{m}^{-2}$ to $2 \cdot 7$ $\mu \mathrm{mol} \mathrm{CO} 2 \mathrm{~g}^{-1}$ protein $\mathrm{s}^{-1}$ at $6.0 \mathrm{~g}$ protein $\mathrm{m}^{-2}$. Assimilation rate increased with increasing activity of RuBPc-o $\mathrm{m}^{-2}$ leaf (both measured at $13^{\circ} \mathrm{C}$ ), but the relationship was not proportional. In nitrogen deficient leaves $\mathrm{RuBPc}-\mathrm{o}$ activity $\mathrm{m}^{-2}$ leaf was only slightly greater than measured $P_{\mathrm{n}}$ (activity range $c .11$ to $22 \mu \mathrm{mol} \mathrm{m} \mathrm{m}^{-2} \mathrm{~s}^{-1}$; assimilation 9 to 14 $\mu \mathrm{mol} \mathrm{CO} 2 \mathrm{~m}^{-2} \mathrm{~s}^{-1}$ ), but assimilation rate did not increase with RuBPc-o activity at higher protein content. If the activity of RuBPc-o at $23^{\circ} \mathrm{C}$ (calculated from measured activity at $13^{\circ} \mathrm{C}$ and corrected using a $Q_{10}$ for this temperature range of 2.4 from Jordan and Ogren (1984)) is compared to $P_{\mathrm{n}}$ measured at $23{ }^{\circ} \mathrm{C}$, enzyme activity greatly exceeds the measured rate of assimilation. Thus, the assimilation rate is regulated by factors other than the amount or activity of RuBPc-o at larger protein contents. Photorespiration was a constant proportion of assimilation with different treatments and, therefore, not responsible for the restriction in assimilation.

The results suggest that some $50 \%$ of the RuBPc-o protein is not activated in leaves with high protein, or alternatively that only half the enzyme sites are functional. Poor correlation of RuBPc-o activity at large protein content, has been observed by Evans (1983) for wheat flag leaves grown in bright light and warm conditions with abundant nitrogen. Accumulation of RuBPc-o without apparent increase in enzyme activity may indicate a function for the protein as nitrogen store. However, Wittenbach, Franceschi, and Giaquinta (1984) rejected the suggestion that RuBPc-o protein is a specific storage protein although it is remobilized to other organs (Peoples, Beilharz, Waters, Simpson, and Dalling, 1980), often early in senescence and particularly with nitrogen deficiency as observed in the present 


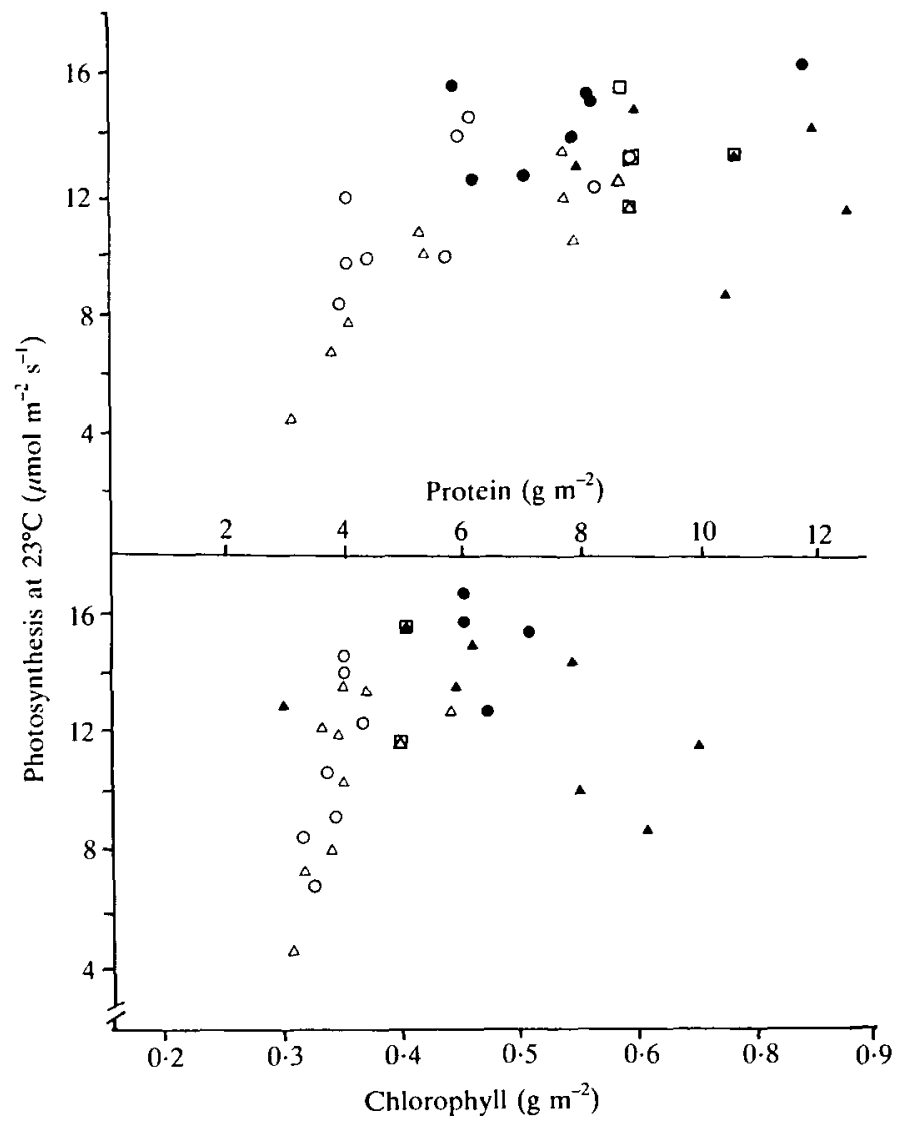

FIG. 7. Assimilation of wheat leaves of different ages, from different growth conditions, measured at $23^{\circ} \mathrm{C}$ in relation to total soluble protein and chlorophyll content; data for leaves of different ages, grown under different nitrate fertilizer, temperature and light. Symbols as in Fig. 1 legend; symbols in boxes for plants grown in $600 \mu \mathrm{mol}$ quanta $\mathrm{m}^{-2} \mathrm{~s}^{-1} P A R$.

study. The enzyme therefore fulfils a dual rôle, primarily as the $\mathrm{CO}_{2}$ fixing enzyme but also as a reserve of nitrogen.

$\mathrm{RuBPc}-\mathrm{o}$ may have low catalytic activity in vitro due to inadequate $\mathrm{CO}_{2}$ or magnesium for activation, or to incorrect $\mathrm{pH}$ (Boyle, 1983) or to decreased availability of inorganic phosphate and increased concentrations of non-reducing sugars, sugar phosphates etc. (Friedrich and Huffaker, 1980; Ku, Prickril, Reger, and Pallas, 1982; Schmidt, Cornelius, Burton, Parry, Millard, Keys, and Gutteridge, 1984) but the importance of these factors in vivo has not been assessed. Products of the PCR cycle might be expected to accumulate in chloroplasts with high rates of $P_{\mathrm{n}}$, inhibiting assimilation. However, measurements (Lawlor, Boyle, Young, Kendall, and Keys, 1987b) showed that RuBP and 3PGA accumulated more with nitrate deficiency and in cool conditions, and ${ }^{14} \mathrm{C}$-labelling indicated accumulation of phosphorylated intermediates under conditions where specific activity and $P_{\mathrm{a}} / \mathrm{RuBPc}-\mathrm{o}$ ratio were generally large. If there is feed-back control of assimilation by the PCR cycle or related intermediates, faster growth in the warm and with additional nitrate should consume products, stimulate RuBPc-o activity and increase photosynthesis. However, no differences in RuBPc-o activity were apparent with temperature, and additional nitrate decreased activity. 
Carboxylation efficiency in leaves at maturity was only slightly smaller with deficient nitrate than with ample, despite the large differences in protein and RuBPc-o carboxylase enzyme, suggesting that carboxylation efficiency is controlled by factors other than total amount of RuBPc-o. The model of Farquhar and von Caemmerer (1982) suggests that the amount of RuBPc-o determines the efficiency in saturating light, and Evans (1983) showed that carboxylation efficiency in wheat is strongly dependent on enzyme activity and, therefore, tissue nitrogen status. However, both carboxylation efficiency and the maximum rate of carbon reduction (Farquhar and von Caemmerer, 1982) may be controlled by other enzyme reactions. Thus fructose bisphosphatase is a potential control step, but it decreased in our experiments in parallel to the RuBPc-o (Lawlor et al., 1987a) as did several other enzymes associated with $\mathrm{CO}_{2}$ assimilation.

The carbon dioxide supply to the active sites of RuBPc-o in vivo could, potentially, limit the rate of photosynthesis but the decrease in $\mathrm{CO}_{2} / \mathrm{O}_{2}$ ratio caused by differences in stomatal conductance would not have been sufficient to cause a large increase in photorespiration to photosynthesis ratio, and indeed none was observed with different growth conditions at any one measurement temperature. Evans (1983) calculated that with larger carboxylase concentration, assimilation rate would have been limited by the conductance of the pathway between intercellular spaces and the site of carboxylation, causing depleting $\mathrm{CO}_{2}$ at the enzyme site and preventing $P_{\mathrm{n}}$ increasing. However, our observations that the enzyme, assayed directly from the tissue, had small specific activity in high protein leaves, conflicts with the interpretation and suggests either that RuBPc-o activity in vivo is controlled by unknown factors or other components of the assimilation system are limiting.

\section{Photorespiration}

The ratio of photorespiration to photosynthesis, measured at constant temperature by several gas exchange methods, was similar for leaves from different treatments, in agreement with the measurements on the RuBPc-o enzyme (Lawlor et al., 1987a). Decreasing the $\mathrm{O}_{2}$ content, from 21 to $2.0 \mathrm{kPa}$, increased assimilation as frequently observed. The $\mathrm{O}_{2}$ response is consistent with the function of RuBPc-o (Jordan and Ogren, 1984); reducing oxygenation inhibits photorespiration and $\mathrm{RuBP}$ becomes available for $\mathrm{CO}_{2}$ assimilation, so that the $\mathrm{O}_{2}$ effect is larger than the measured rates of $\mathrm{CO}_{2}$ release. The smaller proportion of photorespiration to photosynthesis observed at the cool compared to warm measurement temperatures in our experiments may be related to the higher solubility of $\mathrm{CO}_{2}$ compared to $\mathrm{O}_{2}$; low temperatures favour carboxylation over oxygenation. The evidence, from the $\mathrm{O}_{2}$ effect, together with the similar compensation concentrations and similar rates of photorespiration estimated by ${ }^{14} \mathrm{CO}_{2}$, shows that photorespiration of wheat leaves is proportional to assimilation and is unaffected (within the errors of measurement) by growth temperature or nitrate supply, at least until early senescence.

This analysis does not support the conclusion reached by Thomas $(1976,1977)$ that high nitrate fertilization increases the proportion of photorespiration to net photosynthesis. However, Thomas studied mature wheat plants in the field, under hot and rather dry conditions, which may have induced stomatal closure, increasing the proportion (Lawlor, 1979). Our measurements were on young wheat under much cooler conditions and without water stress, so that variations in stomatal conductance and the $\mathrm{CO}_{2} / \mathrm{O}_{2}$ ratio at the active site would not have affected the ratio of $\mathrm{RuBPc}$ to RuBPo activity. The major effects of treatments on stomatal conductance were in bright light, in which cold grown plants had smaller stomatal conductance and smaller net photosynthesis, but it is not known if photorespiration increased as a proportion of photosynthesis or if the decreased 
assimilation was due only to the decreased conductance; RuBPc activity may be inhibited under these conditions (Boyle, 1983).

\section{Photosystems, photochemical efficiency and relation to carboxylation}

Nitrogen deficiency had little effect on the photosystem activity, or photochemical efficiency, although it did decrease the chlorophyll content; cool conditions increased chlorophyll and the PSI and II activity in bright light. The chlorophyll/soluble protein ratio was similar in the different treatments, so it would be expected that the overall capacity for light harvesting and energy transduction would have been greater in leaves from cool conditions compared to warm, and slightly greater with additional nitrate than without. However, differences in photochemistry and chlorophyll were larger than those in assimilation.

Light reactions and electron transport lead to the formation of reductant (NADPH and reduced ferredoxin) and ATP, which are consumed in RuBP synthesis and also in nitrate reduction. There was more $\mathrm{RuBP}$ in nitrate deficient leaves and in cold conditions (Lawlor et al., 1987b) suggesting that photochemical processes were slightly more efficient in those conditions. If RuBP is bound to the active sites of RuBPc-o and RuBP synthesis is not limiting, it might be expected that RuBP content would increase with protein, but this was not so. The complexity of the system for synthesis of RuBP, and the changing demand for it, makes interpretation difficult, particularly as differences in RuBP content were small.

\section{Changes in assimilation and tissue composition with age}

In our experiments assimilation decreased in proportion to protein and chlorophyll as leaves aged, as frequently observed (Čatský, Tichá, and Solárová, 1980; Hall, Keys, and Merrett, 1978), and the decrease was faster in warm than in cool conditions and with deficient nitrate supply, but not for those grown in the $\mathrm{C}+\mathrm{N}$ treatment in which pigment increased and yet assimilation decreased. Loss of assimilation was earlier and greater with nitrate deficiency and in warm conditions, and occurred before the decrease in contents of chlorophyll or protein. Photochemical efficiency decreased by about $50 \%$ in the cold for both $\mathrm{N}$ treatments and $40 \%$ and $20 \%$ in $\mathrm{W}-\mathrm{N}$ and $\mathrm{W}+\mathrm{N}$ conditions respectively. Over the same period RuBP content (Lawlor et al., 1987b) decreased by approximately $65 \%$ and $90 \%$ in $\mathrm{C}-\mathrm{N}$ and $\mathrm{C}+\mathrm{N}$ conditions and $88 \%$ and $81 \%$ in $\mathrm{W}-\mathrm{N}$ and $\mathrm{W}+\mathrm{N}$ conditions respectively. This suggests that $\mathrm{RuBP}$ synthesis is inhibited more than energy transduction with ageing, and is related to the more rapid decrease in carboxylation efficiency with age and deficient nitrogen; decreased assimilation capacity is probably related to changes in stromal enzymes rather than to light harvesting membranes. Nitrogen deficiency appears to stimulate the mechanisms leading to protein degradation, and remobilization of stromal proteins may be faster than those of the thylakoids. Camp, Huber, Broke, and Moreland (1982) observed that RuBPc activity decreased before photosynthetic electron transport, consistent with our data. However, we also observed that chlorophyll and soluble protein decreased together despite the relatively slower loss of photochemical efficiency. Possibly degradation of chlorophyll in thylakoid protein complexes occurs before energy transduction is affected. This is not consistent with the results of Jenkins, Baker, and Woolhouse (1982) and Jenkins and Woolhouse (1982) for Phaseolus vulgaris. Senescing leaves lost reaction centre function, suffered earlier loss of PSI compared to PSII and decreased electron transport, which probably preceeded loss of antenna chlorophyll. Faster loss of RuBPc-o than of photochemical components suggests that the changes in the mechanism responsible for the decrease in assimilation of $\mathrm{CO}_{2}$ involve differential loss of components from chloroplasts, rather than the destruction of complete chloroplasts which has been 
described by Peoples et al. (1980) and Camp et al. (1982). How the structure and function of the carboxylation and photochemical mechanisms are regulated is unknown (Huffaker, 1983).

In conclusion the changes induced in the composition of young leaves and the rates of assimilation by growth temperature and nitrate nutrition are small. Differences in both assimilation and composition become greater between treatments as the leaves age but the amounts of the structural components change in similar proportion; the component or process regulating assimilation cannot be identified. With nitrate deficiency, assimilation per $\mathrm{m}^{2}$ is proportional to the amount of RuBPc-o and chlorophyll per $\mathrm{m}^{2}$ but assimilation did not increase in proportion to protein or chlorophyll as these increased in amount. It appears that part of the RuBPc-o protein produced at high nitrate fertilization is inactive in the leaf as the specific activity is smaller and also the rate of net assimilation is not proportional to RuBPc-o protein. Evidence for control of assimilation by other enzymes is lacking. The ratio of photorespiration to photosynthesis is not affected by growth conditions; the ratio is greater in warm than cool measurement conditions. Additional nitrate does not, therefore, decrease the efficiency of assimilation by changing photorespiration. During senescence, loss of carboxylation efficiency is greater than loss of photochemical efficiency, but the mechanisms regulating the processes are not understood. Control mechanisms in photosynthetic electron transport and associated processes and those operating on carboxylation, are probably different but not understood. However, development and maintenance of assimilation requires that nitrate supply is sufficient to produce a large content of chlorophyll and proteins, and that the supply of nitrate is adequate to minimize their remobilization with age.

\section{ACKNOWLEDGEMENTS}

We thank Keith Plumb for growing the plants, Valerie Mitchell, Janice Turner and Simon Driscoll for excellent technical assistance, Janet Why for preparation of the manuscript and Dr Bill Day for advice on the manuscript.

\section{LITERATURE CITED}

Arnon, D. I., 1949. Copper enzymes in isolated chloroplasts. Polyphenol oxidases in Beta vulgaris. Plant Physiology, 24, 1-15.

Bowes, G., Ogren, W. L., and Hageman, R. H., 1972. Light saturation, photosynthetic rate, RuDP carboxylase activity and specific leaf weight in soybeans grown under different light intensities. Crop Science, 12, 77-9.

BOYLE, F. A., 1983. Factors affecting photosynthesis and research into possible functions for photorespiration. Ph.D. Thesis, University of London.

CAmp, P. J., Huber, S. C., Broke J. J., and Moreland, D. E., 1982. Biochemical changes that occur during senescence of wheat leaves. I. Basis for the reduction of photosynthesis. Plant Physiology, 70, $1641-6$.

ČATSKÝ, J., Tíhá, I., and Solárová, J. 1980. Ontogenetic changes in the internal limitations to bean-leaf photosynthesis. 5. Photosynthetic and photorespiration rates and conductances for $\mathrm{CO}_{2}$ transfer as affected by irradiance. Photosynthetica, 14, 392-400.

Evans, J. R., 1983. Nitrogen and photosynthesis in the flag leaf of wheat (Triticum aestivum L.). Plant Physiology, 72, 297-302.

Farquhar, G. D., and von CaEmmerer, S., 1982. Modelling of photosynthetic response to environmental conditions. In Encyclopedia of plant physiology (NS) Volume 12B. Physiological plant ecology II. Eds O. Lange, P. S. Nobel, C. B. Osmond and H. Ziegler. Springer-Verlag, Berlin. Pp. 549-87.

- and Sharkey, T. D., 1982. Stomatal conductance and photosynthesis. Annual Review of Plant Physiology, 33, 317-45. 
Friedrich, J. W., and Huffaker, R. C., 1980. Photosynthesis, leaf resistances, and ribulose-1,5bisphosphate carboxylase degradation in senescing barley leaves. Plant Physiology, 65, 1103-7.

Hall, N. P., KeYs, A. J., and MerReTt, M. J., 1978. Ribulose-1,5-diphosphate carboxylase protein during flag leaf senescence. Journal of Experimental Botany, 29, 31-7.

Huffaker, R. C., 1983. Protein metabolism. In Plant physiology, Volume VIII, Nitrogen metabolism. Eds F. C. Steward and R. G. S. Bidwell. Academic Press, Orlando, Florida.

JeNkins, G. I., BaKeR, N. R., and WoOlhouse, H. W., 1981. Changes in chlorophyll content and organization during senescence of the primary leaves of Phaseolus vulgaris $\mathrm{L}$. in relation to photosynthetic electron transport. Journal of Experimental Botany, 32, 1009-20.

- and Woolhouse, H. W., 1981. Photosynthetic electron transport during senescence of the primary leaves of Phaseolus vulgaris L. I. Non-cyclic electron transport. Ibid. 33, 467-78.

JORDAN, D. B., and OGREN, W. L., 1984. The $\mathrm{CO}_{2} / \mathrm{O}_{2}$ specificity of ribulose 1,5-bisphosphate carboxylase/oxygenase. Planta, 161, 308-13.

Ku, S. B., Prickril, B. C., Reger, B. J., and Pallas, J. E., 1982. Diurnal fluctuations of RuBP carboxylase activity in peanut leaves. Possible regulation by photosynthetic metabolites. Plant Physiology, 69, supp. Ab. 284.

LAWLOR, D. W., 1979. Effects of water and heat stress on carbon metabolism of plants with $\mathrm{C}_{3}$ and $\mathrm{C}_{4}$ photosynthesis. In Stress physiology in crop plants. Eds H. Mussel and R. C. Staples. WileyInterscience, New York. Pp. 304-26.

Boyle, F. A., Kendall, A. C., and KeYs, A. J., 1987a. Nitrate nutrition and temperature effects on wheat: enzyme composition, nitrate and total amino acid content of leaves. Journal of Experimental Botany, 38, 378-92.

—— Young, A. T., Kendall, A. C., and Keys, A. J., 1987b. Nitrate nutrition and temperature effects on wheat: soluble components of leaves and carbon fluxes to amino acids and sucrose. Ibid. (submitted)

- MAHON, J. D., and Fock, H., 1977. An assimilation chamber for rapid leaf sampling and a gas switching system for control of ${ }^{12} \mathrm{CO}_{2}$ and ${ }^{14} \mathrm{CO}_{2}$ supply. Photosynthetica, 11, 322-6.

LudwiG, L. J., and CANvin, D. T., 1971. The rate of photorespiration during photosynthesis and the relationship of the substrate of light respiration to the products of photosynthesis in sunflower leaves. Plant Physiology, 48, 712-19.

Peoples, M. B., Beilharz, V. C., Waters, S. P., Simpson, R. J., and Dalling, M. J. 1980. Nitrogen redistribution during grain growth in wheat (Triticum aestivum L.). II. Chloroplast senescence and the degradation of ribulose-1,5-bisphosphate carboxylase. Planta, 149, 241-51.

Powles, S. B., and Critchley, C., 1980. Effect of light intensity during growth on photo-inhibition of intact attached bean leaflets. Plant Physiology, 65, 1181-7.

Schmidt, C. N. G., Cornelius, M. J., Burton, S., Parry, M. A. J., Millard, B. N., Keys, A. J., and Gutteridge, S., 1984. Purified ribulose- $P_{2}$ carboxylase from wheat with high specific activity and with fast activation. Photosynthesis Research, 5, 47-62.

ThомаS, S. M., 1976. In Rothamsted Experimental Station Report, Pp. 35-6. 1977. In Rothamsted Experimental Station Report, Pp. 37.

Wittenbach, V. A., Franceschi, V. R., and Giaquinta, R. T., 1984. Soybean leaf storage proteins. In Current topics in plant biochemistry and physiology, 1984. Volume 3. University of Missouri, Colombus. Pp. 19-30. 